\title{
Traditional Agricultural System as Tourism Icon in Jatiluwih Tourism Village, Tabanan Regency, Bali Province
}

\author{
Dewa Putu Oka Prasiasa (Corresponding Author) \\ Sekolah Tinggi Ilmu Manajemen Handayani Denpasar, Bali \\ Email: dewaputuoka18@gmail.com
}

Dewa Ayu Diyah Sri Widari

Akademi Pariwisata (AKPAR) Denpasar, Bali

Email: dewaayusriwidari@gmail.com

Received: February 28, 2019 Accepted: March 22, 2019 Published: March 29, 2019

doi:10.5296/jad.v5i2.14585 URL: https://doi.org/10.5296/jad.v5i2.14585

\begin{abstract}
Traditional farming systems based on local wisdom was applied on a rice field in Jatiluwih Tourism Village is a very attractive tourism icon for tourists. Icons of tourism have been more interesting after Jatiluwih Subak was decreed as part of World Cultural Heritage by UNESCO on July 2012. This research was used qualitative method, aims to know the influence of traditional agricultural systems in Jatiluwih Tourism Village as a tourism icon, to know the attractiveness of traditional agricultural systems in Jatiluwih Tourism Village, and to know the influence of traditional agricultural systems on the tourism development of Jatiluwih Tourism Village. The results show that a fixed traditional farming systems applied by the member of Jatiluwih Subak, namely as pula pali metandur padi bali ring carik most of the farmers in Jatiluwih Tourism Village. Tourist attraction related traditional farming system that was applied in Jatiluwih Tourism Village is the aspect of the activity of each stage in the system of traditional agriculture and its accompanying ceremonies. The influence of traditional agricultural systems against tourism in the Jatiluwih Tourism Village can be seen from the increasingly community involvement in tourism (direct, indirect, and induced), revenue of the operation management of Jatiluwih Tourism Village was increased, as well as the number of tourists visit (foreign and domestic) was increased.
\end{abstract}

Keywords: subak, traditional, farming systems, icons, tourism village. 


\section{Introduction}

Cultural tourism based on the culture and life of the community. Its means the demand for tourism products by tourists linked to the life and culture of local people. Thus, the expected trade-off between cultural with the local community. Reciprocal links must be mutually beneficial.

In the last decades tourism village has emerged as an alternative development strategy for some rural areas. These areas usually concentrate important heritage resources and are, also, losing their traditional productive function and trying to find new activities for stimulating their development (Sharpley, 2005). Environmental and cultural quality are rural areas resources that have become part of the tourism experience sought by more demanding rural tourists and that, to a great extent, defined one of the main objectives of the destination management to provide quality experiences based upon nature and culture (Aranzabal et al., 2009).

Bali is one of the main tourism destinations in Indonesia which has a variety of tourism assets and has attracted the attention of tourists. In line with the development of tourism, in addition to the development of sustainable tourism domination, are not less popular was the development of community based tourism development. There are a number of advantages that can be gained in the development of tourism that involves society, among others, increasingly of business opportunities, increasingly of employment, increasingly people's income and the government, encouraging the preservation of the cultural and historical heritage, encourage environmental rights, the rights to security and order, encourage improvements and growth in the field of the development of other sectors.

As a major tourism destination in Indonesia even in the world, Bali has set the development of cultural tourism as stated in Peraturan Daerah Provinsi Bali Nomor 3 Tahun 1991. In Peraturan Daerah Provinsi Bali Nomor 3 Tahun 1991, chapter I, article 1, paragraph j stated:

"cultural tourism is a type of tourism that is in the development and use of regional culture of Bali are imbued by the Hindu religion that is part of the culture nationwide as a potential dominant basis, which implied a goal of reciprocal relationships between cultural tourism by making it both increases in matching, alignment, and balanced."

As the dominant potential, the main potential of Bali cultural can be formulated from the elements, structure, and experience history, because of the culture of Bali has variety and high diversification in accordance with adagium desa, kala, patra; Balinese culture is a unique system with a clear identity; Balinese culture has roots and supported traditional institutions are sturdy; Balinese culture is a culture that is alive and functional, which has always evolved and developed to maintain the harmony of relationship of tri hita karana; Balinese culture in openess against foreign cultural exhibit flexible, selective, and adaptive and able to receive the foreign elements to belong to its own culture and wealth without losing personality (Mantra, 1996:2-4).

Conception of tourism culture that expects the creation of harmony and balance between tourism organizing with cultural of Bali are expected to support the development of 
community-based tourism in Jatiluwih Tourism Village. According Natori (2001) the goal is quality rights and continuation of the natural and cultural resources, increasing the welfare of local communities and the attainment of a balance between the natural and cultural resources, the well-being of local communities as well as the satisfaction of tourists.

In year 2016 through Surat Keputusan Bupati Tabanan Nomor 180/337/03/2016/HK \& HAM, Jatiluwih Village designated as tourism village. As a tourist attraction, was originally Jatiluwih Village already known since the reign of Netherlands in Bali (Year 1910-1942) due to traditional farming and to the west of the village of Jatiluwih ever established Netherlands Security Headquarters known as tangsi Belanda (Diparda Bali, t.t.:107). It's impact that Jatiluwih Tourism Village did not escape from the visits of tourists. The number of tourist visits to Jatiluwih Tourism Village continued to show an increase, due to the local wisdom in the form of traditional agricultural systems that became an icon of Jatiluwih Tourism Village. On the other hand, local wisdom in the form of traditional agricultural systems that became an icon of Jatiluwih Tourism Village face challenges in the form of the modernization of agricultural equipment is carried out by a group of farmers.

To see the extent to which the traditional agricultural system that became an icon of tourism while also supporting the sustainability of tourism development in Jatiluwih Tourism Village, then the research needs to be done. In addition the study also aims to identify traditional farming system that is applied in Jatiluwih Tourism Village as icons of tourism, the appeal of traditional agricultural systems as a tourism icon that is applied in Jatiluwih Tourism Village, as well as the influence of traditional agricultural systems on the development of tourism in Jatiluwih Tourism Village.

Based on research and studies from the UNDP/WTO and some consultants, Indonesia reached three approaches in drawing up the framework/concept development work from a village into a tourism village that is an indirect interaction, half straight interaction, and direct interaction (UNDP and WTO, 1981). Kementerian Pariwisata dan Ekonomi Kreatif Republik Indonesia (2016:12) provides a definition of tourism village as an area with a specific area and have the potential uniqueness of the typical tourist attraction with its community that is able to create a mix a wide range of attractions and facilities to attract tourists visit her supporters including tourism due to its presence in the area of the city.

The development of tourism villages expected to really reflect the atmosphere of the countryside. Therefore, the concept of extracting products directed at the development of the tourist village of cultural interaction from human to human, and from humans to nature village (Universitas Udayana, 2003). Thus, a variety of tourist attractions which can be developed such as agriculture activities, arts of village, sports, ceremonies and other activities such as meditation, construction of houses, as well as other custom activities. Furthermore, Kementerian Pariwisata dan Ekonomi Kreatif Republik Indonesia (2016:14-15), a tourism village typology according to the type of tourism resources are distinguished into four i.e. tourism village based on uniqueness of natural resources as the main tourist attraction, the tourism village based on uniqueness of local cultural resources as a major tourist attraction, tourism village based on activities/uniqueness of creative work as a major tourist attraction, 
and tourism village based on combination (uniqueness of natural resources, resources of the local culture, and activities/creative works) as a tourist attraction.

According to Peraturan Daerah Provinsi Bali Nomor 9 Tahun 2012, subak is defined as a traditional organization in managing irrigation system and agribusiness which has characteristic of social, religious and economy activities which is historically existed in Balinese community. Other definitions stated by Windia et al. (2015) that subak is the organization which has values. Because subak is not just an organization, but the organization also has a value, than subak can also be referred to as an institution. The values reference by the subak is the value of harmony, in accordance with the essence of tri hita karana. Sutawan (1987) states that the functions of subak are: (a) distribution of water irrigation, (b) maintaining irrigation system, (c) solving the internal conflict, and (d) traditional ceremony related to farming system. Furthermore, Sutawan (1987) argue that subak has several duties, such as maintain food security, environmental conservation, cultural preservation, protection to the traditional value, support agro tourism and provide financial support to members.

This research aims to analyze the influence of traditional agricultural systems in Jatiluwih Tourism Village as a tourism icon, to analyze the attractiveness of traditional agricultural systems in Jatiluwih Tourism Village, and to analyze the influence of traditional agricultural systems on the tourism development of Jatiluwih Tourism Village.

\section{Research Method}

This research used descriptive-qualitatively analysis. A qualitative researcher analyzes data by organizing it into categories on the basis of themes, concepts, or similar features. He or she developed new concepts, formulates conceptual definitions, and examines the relationship among concepts (Neuman, 2000). The choose of the Jatiluwih Tourism Village as location based on consideration that Jatiluwih Tourism Village has a tourist attraction in the form of a traditional farming system of local wisdom, and in 2012 was decreed by UNESCO as a World Cultural Heritage. The informant was determined by purposive. Purposive sampling is referred to as judgmental sampling since it involves the researcher making a decision about who or what study units be involved in the study (Jennings, 2001:139). The informants is a member of the community of Jatiluwih Tourism Village (pekaseh, bendesa adat, and local communities), and Operation Management of Jatiluwih Tourism Village. Data were collected by observation, interview and documents study. As for the data, category, as well as analysis techniques such as Table 1. 
Table 1. The Relationship between Data, Category, and Analysis Techniques

\begin{tabular}{|c|c|c|c|}
\hline Data & Category & Analysis Te & hniques \\
\hline \multirow{2}{*}{$\begin{array}{l}\text { Local wisdom in the form of } \\
\text { agricultural systems }\end{array}$} & $\begin{array}{l}\text { These kinds of ceremonies in the } \\
\text { traditional agricultural systems in } \\
\text { Jatiluwih Tourism Village }\end{array}$ & $\begin{array}{l}\text { Descriptive } \\
\text { analysis }\end{array}$ & qualitatively \\
\hline & $\begin{array}{l}\text { Stages in traditional agricultural system } \\
\text { activities in Jatiluwih Tourism Village }\end{array}$ & $\begin{array}{l}\text { Descriptive } \\
\text { analysis }\end{array}$ & qualitatively \\
\hline $\begin{array}{l}\text { The traditional agricultural systems } \\
\text { as a tourist attraction }\end{array}$ & $\begin{array}{l}\text { Traditional agricultural systems that } \\
\text { become tourist attraction (natural and } \\
\text { artificial) }\end{array}$ & $\begin{array}{l}\text { Descriptive } \\
\text { analysis }\end{array}$ & qualitatively \\
\hline \multirow{3}{*}{$\begin{array}{l}\text { The influence of traditional } \\
\text { agricultural systems on the } \\
\text { development of tourism in } \\
\text { Jatiluwih Tourism Village }\end{array}$} & $\begin{array}{l}\text { The development of local community } \\
\text { involvement in tourism }\end{array}$ & $\begin{array}{l}\text { Descriptive } \\
\text { analysis }\end{array}$ & qualitatively \\
\hline & The development income & $\begin{array}{l}\text { Descriptive } \\
\text { analysis }\end{array}$ & qualitatively \\
\hline & $\begin{array}{l}\text { The development of the number of visit } \\
\text { by tourist }\end{array}$ & $\begin{array}{l}\text { Descriptive } \\
\text { analysis }\end{array}$ & qualitatively \\
\hline
\end{tabular}

\section{Results and Discussion}

\subsection{The Influence of Traditional Agriculture Systems in Jatiluwih Tourism Village as a Tourism Icon}

The community of Jatiluwih Tourism Village as a relegius agricultural societies maintain agricultural system. Rice terracing inherited hereditary passage not only made an asset and tourist attraction in the development of tourism villages, but also as a part of culture and farming systems that are applied in society.

An agricultural system that is applied by the citizens with regard to water control system in rice planting ceremony. The ceremony such as magpag toya, ngendag tanah carik, ngurit, negtegang, ngerasakin, pangawiwit (nuwasen), ngekambuhin, pamungkah, penyepian, pangarestitian, mesaba, ngadegang Batari Sri (Batari Nini), manyi, and mantenin.. All the ceremonies are still retained by each citizen of subak as a habit (tradition) that indeed should be implemented. The tradition is inherited from ancestors and continues to be implemented, either before or after the determination of subak by UNESCO as a World Cultural Heritage.

In addition to as habits (traditions), implementation of the ceremonies associated with the agricultural activities continue to be held because it is an obligation as human beings. The villagers had the realization that Jatiluwih Tourism Village as the farming community has indeed should keep nature (agricultural land) that is the grace of God. As a form of thanks for the gift that has been given, the public should keep harmonious relationship with God and 


\section{MInstitute Macrothink $_{\text {Int }}$}

nature (parhyangan and palemahan) as part of tri hita karana. Rice cropping system that applied also continue to be carried out by the citizens of subak. Jatiluwih Subak rice cropping system divides into two periods. The first period, planting padies Bali (local) on January, with the harvest between the months of May and June. The second period, planting of rice varieties (such as serang, mangsur, sigelis, PB and IR) on August, with a harvest on November. The application of the system of planting padies Bali (local) as an effort to maintain the availability of red rice, white rice, and black rice as symbolic of tri datu (three color that sacred by Hindu, namely red, white and black). For the holding of religious ceremonies, the three color rice was needed as a means of offerings (banten) and is a symbol of tri datu.

The importance of the role of red rice, white rice, and black rice as a means in religious ceremonies, rice cropping system should have been applied by Jatiluwih Subak increasingly maintained and preserved. It is also associated with the presence of water as world heritage, not only need to keep it preserved terracing but agricultural culture and its accompanying ceremonies must continue to be implemented. Rice cropping system and its accompanying ceremonies become components of the criterion with the cropping system on other agricultural organizations in the world. Local farmers still use cow/buffalo to plow rice fields. Another reason that makes farmers still use cow/buffalo to plow rice fields, because their land are far away from the street so that water could not be traversed by a tractor. In addition, the use of cow/buffalo to plow rice fields to reach the difficult parts of the rice fields (such as the corner of rice fields) and does not cause air pollution. This can not be done if farmers plowing a rice field at the time of use of the equipment in the form of tractor. The use of cow/buffalo to plow rice fields by farmers is one of the tourist attraction of the traditional agricultural system which is an icon of tourism in Jatiluwih Tourism Village.

Traditional of the agricultural system that applied by community of Jatiluwih Tourism Village. Local communities do the stages of farm to plant padies Bali is also known as pula pali metandur padi bali ring carik. As for the sequence is as follows.

a. Magpag toya, the ceremony is intended to let water flow through the path already specified. The ceremony was held at water sources such as dams (empelan) that is in the location of Jatiluwih Tourism Village.

b. On the first water division (tembuku aya), ceremony was held with the objective to clean water. The ceremony was dedicated to Lord Brahma. At upstream rice fields (ulun carik), was held the ceremony of pemaripurna addressed to Hyang Iswara.

c. Started tilling (ngendagin). At this stage in a rice field is held ceremony in order to make farmers safely and equipment can function according its use.

d. Mewinih/ngurit, this stage was marked by a ceremony in order to seed rice can grow well and do not disturb the pest or disease.

e. Ngerasakin, the aim is (1) clean the rice ahead of planting rice, (2) ngelabain pests and diseases, the purpose is to make the rice seeds to be planted are not tampered with pests. A ceremony was held before the rice seeds are scattered in the rice fields. 


\section{Macrothink

f. After the rice seeds are planted in the rice fields, then held the ceremony of newasain/nuasen. The purpose of this ceremony was seedlings are growing well.

g. After the rice was one-month seven days years old (according to the Balinese calendar) or 42 days, held the ceremony of tutug kambuhan. The purpose of this ceremony is to make the rice grows well.

h. Toward rice fruitful, to present a sour fruits (at least three). The goal is to make the rice flower grows perfectly.

i. Towards harvest (four months or 140 days), held the ceremony of ngusaba. Ngusaba is implemented in two places, namely (1) ngusaba at upstream rice fields (ulun carik or bedugul), held twice namely ngusaba alit and one ngusaba gede; (2) ngusaba in rice fields as much once. At a ceremony symbolically ngusaba rice planed as much as one handheld.

j. After dried, pounded rice, and rice yield collision was used to fill in as much as a single wave. Once cooked, the wave is presented using don dapdap and dedicated to the rice fields, the family shrine were, on the home page (natah), waterways and holy places, as well as places to present offerings every day. The goal is to get the savings or penginih-inih.

k. Before the harvest is done, held a ceremony ngadegang Betari Nini. To realize purusa pradana, taken 66 rod rice. Rice were split in half, 33 stems of rice taken as symbol of purusa and 33 remaining as a symbol of pradana.

1. Harvest.

m. Rice after the ceremony nyangket done at home, the goal is to make of Betari Sri can take place. After the ceremony is followed by rice in storage barns.

n. After paddy rice barns, riding on ceremony. The ceremony is known as mantenin. The purpose so Betari Sri come from the four corners gathered in barns.

o. Mantenin, three days after starting to lose rice symbolically as much as one bunch.

p. Rice belt after one derived from the barn directly, then cooked and pounded rice is offered to the rice paddies and sanctuaries in the environment of rice owners.

q. Rice lowerned overall from barns to be processed in accordance with needed of the owner.

\subsection{The Attractiveness of Traditional Agricultural Systems in Jatiluwih Tourism Village}

Determination of subak as World Cultural Heritage can preserve agricultural culture is included in the processing of agricultural land use in traditional ways. In the development of tourism villages, farming culture in the form of plowing a rice field using cow/buffalo continues to be preserved. Because of the rice field ploughing with cows/buffaloes is a tourist attraction that reflect a rural atmosphere, with regards to the life of the local community which is traditional as well as maintain the ancestral tradition of sustainability. It is also in 
line with the requirements of a designation of the village into a tourism village should have objects that are interesting to offer (attractions), easily reachable by means of transport (accessibilities), and possible means of tourism facilities (amenities).

Other agricultural cultures are maintained in regard the development of Jatiluwih Tourism Village is activity of repeal of the land rice seeds to propagate (ngabut bulih). This addition reflects the activity of agricultural culture, can become a tourist attraction which is very attractive for tourists. In addition to this activity can be part of a package tour to plant paddy, which consists of creating a rice seedbed, sow rice seeds on the grounds of the seedbed, ngabut bulih, and planting rice. Ngusaba ceremony as part of an agricultural culture continue to be preserved. This is to support application of the system of traditional agriculture. The ceremony was preceded by the installation of a lelakut (a type of doll) to scare away birds in rice fields in order not to eat the rice. Installation of lelakut in rice fields is an attraction for tourists who come to the World Heritage area. The tourists made lelakut as the object photos.

The harvest of Bali's paddy (red rice) in Jatiluwih Tourism Village is a very interesting attractions for tourists. This is because the addition can only be carried out once a year, as well as the equipment used to harvest the paddy use the cutting tool of the traditional rice known as anggapan. The harvest of Bali's paddy by traditionally in Jatiluwih Tourism Village on July 2017 made one attraction at one time attractions for tourists who follow the Jatiluwih Agriculture Festival 2017 which runs from 01 July until 13 August 2017. In the festival in addition to the attraction of the harvest of Bali's paddy (red rice), also featured Subak Parade, attractions ploughing rice fields (metekap), and catching eel. All the attractions as well as the appeal shown associated with maintened traditional farming system in Jatiluwih Tourism Village. All the cultural circuit that follows the traditional farming system can be a tourist attraction.

\subsection{The Influence of Traditional Agricultural Systems on the Tourism Development of Jatiluwih Tourism Village.}

Traditional farming systems followed by a traditional ceremony in the traditional agricultural system in Jatiluwih Tourism Village has influenced to tourism development in the village. As for the developments will be seen from Jatiluwih Tourism Village community engagement in the field of tourism, income from tourism activity, and the number of tourists visiting to Jatiluwih Tourism Village.

The development of tourism has impact on community involvement in Jatiluwih Tourism Village. Such involvement can be classified i.e. direct, indirect, and induced. Direct involvement of jobs that are available on the ranks of the tourism industry. Indirect involvement of jobs that are available on a factory, shops and other businesses needed by entrepreneurs and tourism organization directly serving the tourists. Induced involvement i.e. jobs that would be created resulting from spending on the people who work directly or indirectly on tourism industry. According Prasiasa and Widari (2017:282) the amount of labor that is absorbed from their respective business tourism in the Jatiluwih Tourism Village of assignment prior to World Cultural Heritage (2010-2011) pointed out that of the nine existing tourism efforts, the number of labor is absorbed as many as 48 people. The amount of $62.5 \%$ 
or 30 people came from Jatiluwih Village, while $37.5 \%$ or 18 people come from outside Jatiluwih Village. After determination of the subak as World Cultural Heritage (in 2012), the amount of labor that is absorbed from tourism has increased efforts to become as much as 63 people where 43 people came from Jatiluwih Village and 23 people coming from outside Jatiluwih Village.

The local community also much absorbed on direct employment in tourism businesses that are located in Dusun Gunungsari and Dusun Jatiluwih Kangin. Direct employment in tourism efforts include work that is available on accomodation (lodgings and villas), restaurants, food and beverages, and All Terrain Vehicle (ATV) rentals. The number of direct labor on business tourism in Jatiluwih Tourism Village reaches 63 people. Of that number $68.25 \%$ or 43 people came Jatiluwih Village, whereas $31.75 \%$ or 20 people coming from outside Jatiluwih Village. Comparison of the amount of labor that is absorbed in the tourism business before and after the determination subak as World Cultural Heritage, an increase in as many as 15 people or of $31.25 \%$. The work of the community of Jatiluwih Village as farmers when associated with the types of jobs including indirect employment. As well as the work of the society as a breeder, range chicken or work at businesses in packaging and processing of red rice that are sold as souvenirs to tourists. Induced employment precedents also has a role in the absorption of jobs although it played not too large. Included in induced employment that work on the stalls or shops that sell items daily living needs (basic food) needed by local communities (Widari, 2015).

Tourist expenditures made in tourist spots can be a source of income for local communities. The income earned by community of Jatiluwih Tourism Village comes from the efforts of tourism as well as the management of tourism village. In business tourism, income received by entrepreneurs of tourism after the determination of subak as World Cultural Heritage has increased. Tourism entrepreneurs state that after determination of subak as World Cultural Heritage revenue from businesses that had increased by $20 \%$ to $40 \%$. Increased income fluctuate depending its effort and season. The magnitude of the increase in people's income outside agriculture (or from business tourism) ranges between IDR 1.000.000 to IDR 5.000.000 per month.

Income earned from employment in tourism businesses as well as management of tourism village (direct jobs), is the income that is received directly by local communities. Likewise with the revenue obtained by the people who work on the operational management of the provider of the tourist attraction of Jatiluwih. Prior to the determination of subak as World Cultural Heritage, income from management of tourism village is managed by desa dinas. From the gross revenue received, distributed to collect wages (20\%), then the rest is divided into two, namely to Government District of Tabanan (50\%) and for desa dinas (50\%). Furthermore, the revenue received by the village of distributed again for bailouts (5\%), the cost of cleanliness and Desa Dinas (35\%), Desa Adat Jatiluwih (39\%), and Desa Adat Gunungsari (21\%).

After determination of subak as World Cultural Heritage, based on Cooperation Agreement Government's Tabanan Regency with Jatiluwih Village, Desa Pakraman Jatiluwih, Desa 
Pakraman Gunungsari, and Jatiluwih Subak year 2016, from gross income received after deducting insurance premiums then performed the following distribution: 30\% operational management costs, $10 \%$ for development, $5 \%$ for promotion, management and operational costs by $10 \%$. Then, from the rest of the revenue is distributed to Regional Government of Tabanan Regency $45 \%$ and $55 \%$ for the village. Income received by the village distributed for Jatiluwih Village 25\%, Desa Pekraman Jatiluwih 25\%, and 30\% for Desa Pakraman Gunungsari, Subak Jatiluwih 21\%, Subak Abian Jatiluwih 2\%, and Subak Abian Gunungsari 2\% (Manajemen Operasional DTW Jatiluwih, 2017).

The income received from management of tourism village used to finance religious ceremonies. In organizing religious ceremonies like pujawali in pretending, usually community imposed a number of mandatory dues. However, due to the distribution of revenue to desa dinas and desa adat, local community of Jatiluwih not longer need to pay compulsory dues at a time when there is a religious ceremony. For local people, this can alleviate costs that must be incurred for religious ceremonies. Indirectly, the community also benefit from management of the tourism village. The impact of developing Jatiluwih Tourism Village as a tourist attraction for increasing income received by the community both directly and indirectly supports Sally's research (2015), mentioning that local communities get economic benefits from tourism management.

Based on data from Operational Management of Jatiluwih Tourist Attraction (2018) gross income earned year 2014 reached IDR 3.096.816.500; on year 2015 reached IDR 2.970.430.046; year 2016 reached IDR 4.683.655.500; and year 2017 reached IDR 9.294.100.000. Tourists visiting Jatiluwih Tourism Village year 2014 as much as 165,144 people, year 2015 as many as 164.358 people, year 2016 as many as 213.509 people, and year 2017 as much 250.973 people. Total tourists visiting Jatiluwih for four years (2014 2017) as many as 793.984 people (Manajemen Operasional DTW Jatiluwih, 2018). Tourists who visit to Jatiluwih Tourism Village in addition caused by Jatiluwih Subak as part of World Cultural Heritage, as well as an environment that offered really reflect the environment with an atmosphere in Bali, image and quality of the destinations. Agricultural system that blends in with the traditional culture in the field of agriculture which is still awake and well maintained with a typical agricultural character of Jatiluwih also became push factor.

\section{Conclusion}

Traditional agricultural systems that are applied by the citizens of Jatiluwih Subak associated with traditional ceremony in Bali rice cropping system that is also known as pula pali metandur padi bali ring carik still run even though there are influences of icon in tourism. Tourist attraction related traditional farming system that is applied in Jatiluwih Tourism Village is aspect of the activity of each stage in traditional system of agriculture and accompanying ceremonies. The influence of traditional farming system against tourism in Jatiluwih Tourism Village in the form of increasing community involvement in tourism (direct involvement, indirect involvement, and induced), increasingly income from management of Jatiluwih Tourism Village, as well as the number of tourists (foreign and domestic) has increased. 


\section{Macrothink}

\section{References}

Aranzabal, I., Schmitz, M., \& Pineda, F. (2009). Integrating Landscape Analysis and Planning: A Multi-Scale Approach for Oriented Management of Tourist Recreation. International Journal Environmental Management, 44(5), 938-951. https://dx.doi.org/ 10.1007/s00267-009-9371-z.

Diparda Bali. (t.t.). Informasi Objek dan Daya Tarik Wisata di Bali. Denpasar: Bagian Pemasaran dan Publikasi.

Sally, M. F. (2015). Tourism Management in World Heritage Sites and its Impact on Economic Development in Mali and Ethiopia. Procedia Social and Behavioral Sciences, 211: 595-604. https://dx.doi.org.10.1016/j.sbspro.2015.11.078.

Jennings, G. (2001). Tourism Research. Australia: John Wiley \& Sons Australia, Ltd.

Kementerian Pariwisata dan Ekonomi Kreatif Republik Indonesia. (2016). Pedoman Pengembangan Desa Wisata. Jakarta: Direktorat Pemberdayaan Masyarakat Destinasi Pariwisata.

Manajemen Operasional DTW Jatiluwih. (2018). Laporan Perkembangan Pengelolaan DTW Jatiluwih Tahun 2018.

Mantra, I. B. (1996). Landasan Kebudayaan Bali. Denpasar: Yayasan Dharma Sastra.

Natori, M. (2001). A Guide Book for Tourism-Based Community Development. Yokohama: Asia Pacific Tourism Exchange Center.

Neuman, W. L. (2000). Social Research Methods: Qualitative and Quantitative Approaches. Boston: Allyn \& Bacon.

Peraturan Daerah Provinsi Bali Nomor 3 Tahun 1991 tentang Pariwisata Budaya.

Peraturan Daerah Provinsi Bali Nomor 9 Tahun 2012 tentang Subak.

Prasiasa, D. P. O., \& Widari, D. A. D. S. (2017). Desa Wisata Potensi dan Strategi Pengembangan. Denpasar: Pustaka Larasan.

Sharpley, R. (2005). Managing the Countryside for Tourism: A Governance Perspective. In Pender and Sharpley (Eds.), The Management of Tourism (pp.245-256). London: Sage Publications.

Surat Keputusan Bupati Tabanan Nomor: 180/337/03/HK\&HAM/2016 tentang Penetapan Desa Jatiluwih sebagai Desa Wisata di Kabupaten Tabanan.

Sutawan, N. (1987). Farmer-Managed Irrigation Systems and the Impact of Government Assistant: A Note from Bali, Indonesia. International Irrigation Management Institute (IIMI) and Water and Energy Commission Secretariat (WECS) of the Ministry of Water Resources, Government of Nepal, Colombo, Sri Lanka.

UNDP \& WTO. (1981). Tourism Development Plan for Nusa Tenggara, Indonesia. Madrid. 
Universitas Udayana. (2003). Laporan Penelitian Studi Pengembangan Desa Wisata Ambengan Berbasiskan Budaya dan Kerajinan Rakyat. Denpasar: Program Studi Pariwisata.

Widari, D. A. D. S. (2015). Perkembangan Desa Wisata Jatiluwih Setelah UNESCO Menetapkan Subaknya Sebagai Bagian dari Warisan Budaya Dunia. JUMPA, 2(1), 61-78. https://doi.org/10.24843/jumpa.2015.v02.i01.p04.

Windia, I W., Sudarta, W., \& Astiti, W. S. (2015). Sistem Subak di Bali (Kajian Sosiologis). Denpasar: Udayana University Press.

\section{Copyright Disclaimer}

Copyright for this article is retained by the author(s), with first publication rights granted to the journal.

This is an open-access article distributed under the terms and conditions of the Creative Commons Attribution license (http://creativecommons.org/licenses/by/4.0/). 